\title{
Penerapan Kawasan Tanpa Rokok Berdasarkan Peraturan Daerah Nomor 5 Tahun 2015 Di Kabupaten Wajo
}

\author{
Muharawati Muharawati \\ Sekolah Tinggi Ilmu Hukum Lamadukelleng, Sengkang \\ Email Correspondensi:fadel_rhn@yahoo.com
}

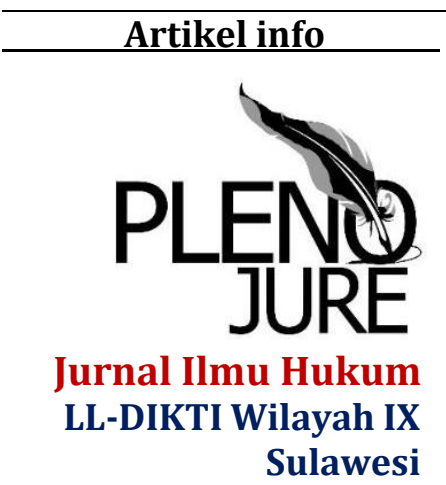

Artikel history:

Received : 17 Mei 2020

Revised : 08 Juni 2020

Accepted : 20 Juni 2020
Abstrak. Penerapan Kawasan Tanpa Rokok berdasarkan Peraturan Kabupaten Wajo bertujuan untuk mendeskripsikan faktor yang mempengaruhi penerapan Kawasan Tanpa Rokok berdasarkan peraturan yang ada, dan sebagai bahan referensi lanjut bagi peneliti dan pengembang sektor hukum di Kabupaten Wajo. Penelitian ini menggunakan pendekatan kualitatif dengan jenis penelitian deskriptif. Metode pengumpulan data melalui wawancara, observasi dan studi dokumentasi. Tahap dalam teknik analisis data yang digunakan yaitu reduksi data, penyajian data, dan penarikan kesimpulan. Hasil penelitian menunjukkan Penerapan kawasan tanpa rokok berdasarkan regulasi di Kabupaten Wajo namun belum sepenuhnya terlaksana dengan baik. Sosialisasi telah dilakukan sejak diberlakukannya kebijakan kawasan tanpa rokok. Namun, Pemerintah Daerah Kabupaten Wajo belum ada tim khusus untuk mendukung dan mengontrol aktivitas merokok di lingkungan rumah sakit, dalam penganggaran pada peralatan pihak rumah sakit sudah memasang tanda larangan merokok tapi belum membuat tempat khusus untuk merokok. Kesiapan pelaksana belum sepenuhnya menunjukkan sikap yang mendukung kebijakan kawasan tanpa rokok di rumah sakit Umum Daerah Lamaddukelleng Sengkang, masih ada beberapa pegawai atau staf yang acuh tak acuh terhadap pengunjung yang merokok di lingkungan rumah sakit, namun sebagian juga sudah ada pegawai yang peratian terhadap kawasan tapa rokok. Pihak rumah sakit belum menyiapkan pedoman yang jelas terkait Kawasan Tanpa Rokok berdasarkan Peraturan Kabupaten Wajo.

Abstract. The application of No Smoking Area based on Wajo Regency Regulations aims to describe the factors that influence the application of No Smoking Area based on existing regulations, and as further reference material for researchers and developers of the legal sector in Wajo Regency. This study uses a qualitative approach to the type of descriptive research. Data collection methods through interviews, observation and documentation study. The stages in the data analysis technique used are data reduction, data presentation, and concluding. The results showed that the application of a nonsmoking area was based on regulations in Wajo District, but it 
was not yet fully implemented. The socialization has been carried out since the enactment of the no-smoking area policy. However, the Regional Government of Wajo Regency has not had a special team to support and control smoking activities in the hospital environment, in budgeting on the equipment the hospital has put up a smoking ban sign but has not created a special place for smoking. Implementing readiness has not fully demonstrated the attitude that supports the policy of non-smoking areas in the Lamaddukelleng Sengkang Regional General Hospital, there are still several employees or staff who are indifferent to visitors who smoke in the hospital environment, but some also have employees who are concerned about the area cigarettes. The hospital has not yet prepared clear guidelines regarding the No Smoking Area based on Wajo Regency Regulations.

\section{Keywords:}

peraturan

kabupaten;

regulasi daerah;

bebas rokok;

\section{PENDAHULUAN}

Kesehatan merupakan investasi untuk mendukung pembangunan dengan upaya meningkatkan kualitas sumber daya manusia. ${ }^{1}$ Pembangunan nasional merupakan usaha meningkatkan kualitas manusia dan masyarakat Indonesia yang dilakukan secara berkesinambungan, ${ }^{2}$ yaitu upaya besar bangsa Indonesia dalam meluruskan kembali arah pembangunan nasional yang telah dilakukan menuntut reformasi total kebijakan pembangunan di segala bidang namun relahkah anda mati demi sebatang rokok. Tujuan pembangunan kesehatan adalah meningkatkan kesadaran, kemauan, dan kemampuan hidup sehat bagi setiap orang agar terwujud derajat kesehatan masyarakat yang optimal melalui terciptanya masyarakat, bangsa, dan Negara Indonesia yang ditandai oleh penduduknya hidup dalam lingkungan dengan perilaku hidup sehat. $^{3}$

Rokok merupakan salah satu yang membuat lingkungan sekitar kita menjadi tidak sehat, karena asap yang dihasilkannya mengandung banyak zat berbahaya yang dapat mengakibatkan tercemarnya lingkungan serta mengganggu kesehatan penikmatnya maupun orang disekitarnya. ${ }^{4}$ Tujuanya untuk mengetahui sebagian besar orang bisa meninggal dikarenakan mengonsumsi rokok dengan berlebih. Awalnya memang tidak terasa sakit, tetapi semakin lama seseorang mengonsumsi rokok, maka akan banyak timbul

\footnotetext{
${ }^{1}$ Ariyadin. 2011. Rokok Anda: Relakah Mati demi Sebatang Rokok?. Yogyakarta: Manyar Media. hal, 41

2 Wati, A. R. A. (2017). Penerapan Kawasan Tanpa Rokok Berdasarkan Peraturan Daerah Kota Metro Nomor 4 Tahun 2014. JURNAL HIMA HAN, 4(2).

${ }^{3}$ Chazawi, A. (2001). Kejahatan terhadap tubuh dan nyawa. Jakarta: Raja Grafindo Persada. Hal, 42

${ }^{4}$ Marpaung, L. (2000). Tindak Pidana Terhadap Tubuh dan Nyawa (Pemberantasan dan Prevensinya). Jakarta: Sinar Grafika. Hal, 51
} 
berbagai penyakit dalam tubuhnya. Rokok merupakan salah satu produk tembakau yang dimaksudkan untuk dibakar dan dihisap asapnya termasuk rokok kretek, rokok putih, cerutu atau bentuk lainnya yang dihasilkan dari tanaman nicotiana rustica, nicotiana tabacum dan spesies lainnya yang asapnya mengandung nikotin dan dapat menyebabkan timbulnya penyakit.

Dasar pemikiran dimulai dari Undang-Undang Republik Indonesia Nomor 36 tahun 2009 Tentang Kesehatan, sebagai warga negara yang baik kita patut untuk menjaga kenyamanan orang lain, karena asap rokok itu bagi sebagian orang sangat mengganggu. Perpedoman pada Undang-Undang Republik Indonesia Nomor 9 Tahun 2015 tentang Pemerintahan Daerah, dan pembentukan Peraturan Daerah Nomor 5 tahun 2015 tentang Kawasan Tanpa Rokok Kab Wajo merupakan amanah Undang-Undang Nomor 36 Tahun 2009 tentang Kesehatan.

Tujuan dari beragam institusi yang telah menerapkan Kawasan Tanpa Rokok umumnya adalah tempat sarana kesehatan seperti rumah sakit, puskesmas, toko obat atau apotek, laboraturium dan tempat kesehatan lainnya, tempat proses belajar mengajar seperti sekolah, perguruan tinggi, dan tempat pendidikan lainnya, tempat ibadah seperti masjid, gereja, pura dan tempat ibadah lainnya, beberapa tempat kerja seperti perkantoran pemerintah dan perkantoran swasta serta tempat umum seperti pusat perbelanjaan, tempat kegiatan anak-anak, angkutan umum, tempat umum seperti taman kota, tempat sarana olahraga dan tempat lainnya yang ditetapkan. Disusunnya kebijakan tersebut menunjukkan komitmen kuat Pemerintah Daerah dalam pencegahan dan melindungi masyarakatnya dari bahaya rokok.

Masalah tentang rokok merupakan sebuah dilema bagi Pemerintah. ${ }^{5}$ maka Pemerintah harus berupaya untuk meningkatkan kualitas kesehatan masyarakat dengan membuat aturan yang ketat tentang rokok namun dilain pihak ada kelompok masyarakat yang terancam keberlangsungan hidupnya apabila aturan tersebut dijalankan, karena ada ratusan ribu orang yang menggantungkan hidupnya pada industry rokok. Indusri rokok menyerap begitu banyak tenaga kerja yang mayoritas adalah para wanita yang tidak lain yaitu untuk membantu perekonomian keluarga, selain itu juga ada petani tembakau yang akan dirugikan apabila industri rokok ditutup.

Peraturan Pemerintah Daerah Nomor 5 Tahun 2015 tentang Kawasan Tanpa Rokok mempunyai tanggung jawab untuk melindungi dan meningkatkan kesehatan masyarakat namun jika harus memperhatikan kesejahteraan para buruh pabrik rokok dan petani tambakau. Oleh karena itu sebagai jalan keluar maka pada tahun 2015 Pemerintah Kab Wajo telah mengeluarkan Peraturan Daerah Nomor 5 Tahun 2015 tentang Kawasan Tanpa Rokok. Peraturan Daerah ini tidak bermaksud melarang orang untuk merokok, hanya saja mengatur supaya orang tidak merokok di sembarangan tempat. Apabila berada ditempat umum atau tempat kerja yang termasuk kawasan tanpa rokok, maka seseorang dapat merokok asalkan di tempat khusus merokok yang telah disediakan.

Penyediaan tempat khusus merokok wajib dilakukan oleh pimpinan atau penanggung jawab kawasan tersebut. Dibentuknya Peraturan Daerah Kab Wajo

\footnotetext{
5 Ellizabet, A. L. (2010). Stop merokok; sekarang atau tidak sama sekali. Bangun Tapan.
}

Yogyakarta: Garai Ilmu. Hal, 43 
Nomor 5 Tahun 2015 Tentang Kawasan Tanpa Rokok merupakan landasan hukum untuk setiap orang atau badan guna mendapatkan hak yang sama untuk kawasan tanpa rokok yang sehat, dan setiap orang atau badan melaksanakan kewajiban untuk memelihara, dan menjalankan peraturan yang telah dibuat guna menjaga kelestarian lingkungan hidup.

Peraturan Daerah tentang Kawasan Tanpa Rokok merupakan langkah untuk melindungi masyarakat dari ancaman perokok aktif sehingga budaya dan kebiasaan masyarakat tersebut dalam hal ini kebiasaan merokok mempengaruhi terciptanya aturan tentang larangan merokok di tempat umum dengan dibuatnya Kawasan Tanpa Rokok. Olehnya artikel ini akan mengurai pokok permasalahan yang dirumuskan sebagai berikut: 1. Bagaimanakah penerapan Kawasan Tanpa Rokok berdasarkan Peraturan Daerah Kab Wajo Nomor 5 Tahun 2015? 2. Apakah faktor penghambat penerapan dari Kawasan Tanpa Rokok berdasarkan Peraturan Daerah Kab Wajo Nomor 5 Tahun 2015 ?

\section{METODE}

Jenis dan lokasi penelitian yang digunakan dalam penulisan ini adalah penelitian lapangan (field research), penelitian yang mengkaji kolerasi antara kaidah hukum dalam bentuk ketentuan peraturan perundang-undangan. Lokasi penelitian dalam hal ini untuk mendapatkan data dan informasi yang diperlukan berkaitan dengan permasalah dan pembahasan penulisan ini, maka penulis melakukan penelitian dengan memilih lokasi penelitian di wilayah Pemerintahan Daerah dan RSUD Kab Wajo, dengan alasan bahwa di wilayah Pemerintahan Daerah dan Rumah Sakit Umum Lamaddukkeleng adalah tempat instansi yang bisa memberi Keterangan tentang Penegakan Perda Di Kabupaten Wajo.

Upaya pendekatan pada obyek yang diteliti serta pokok permasalahan, maka spesifikasi pada penelitian ini adalah penelitian yang bersifat normatifempiris yaitu penelitian yang mengkaji kolerasi antara peraturan-peraturan yang berlaku. Adapun sumber data yang dapat diperoleh dalam penelitian ini adalah : (1) Data primer, yaitu data yang diperoleh secara langsung melalui wawancara dengan pihak yang berkompoten terkait dengan penulisan ini. (2) Data sekunder, yaitu data yang diperoleh dari dokumen dari instansi lokasi penelitian, literatur, serta peraturan perundang-undangan. Data sekunder terdiri dari bahan hukum primer, bahan hukum sekunder, serta bahan hukum tersier yang dikumpulkan berdasarkan topik permasalah yang telah dirumuskan: Undang-Undang Republik Indonesia No 36 tahun 2009 Tentang Kesehatan, Undang-Undang Republik Indonesia Nomor 9 Tahun 2015 tentang Pemerintah Daerah, Peraturan Pemerintah Republik Indonesia No 41 tahun 1999 tentang Pengendalian Pencemaran Udara, Peraturan Pemerintah Republik Indonesia No 19 tahun 2003 tentang Pengamanan Rokok bagi Kesehatan, Instruksi Menteri Kesehatan Republik Indonesia Nomor 84/Menkes/Inst/II/2002 tentang Kawasan Tanpa Rokok di Tempat Kerja dan Sarana Kesehatan, Peraturan Daerah Kab Wajo Nomor 5 Tahun 2015 tentang Kawasan Tanpa Rokok.

Metode pengumpulan data yang digunakan dalam penelitian ini antara lain menggunakan metode-metode sebagai berikut: a. Studi dokumen, yaitu dengan mempelajari dokumen-dokumen yang berhubungan dengan masalah yang penulis teliti. b. Wawancara, yaitu dengan melakukan tanya jawab secara 
lisan terhadap pihakpihak terkait dalam penulisan Proposal ini. Dalam hal ini, penulis melakukan wawancara dengan beberapa nara sumber. Instrumen penelitian yang dipakai untuk memperoleh data-data penelitian saat sesudah memasuki tahap pengumpulan data dilapangan adalah wawancara dan dokumen. Instrumen penelitian inilah yang akan menggali data dari sumbersumber informasi sebagai berikut : Masyarakat umum Polisi Pamong Praja dan sekuriti Rumah Sakit Umum Daerah Lamaddukelleng Kabupaten Wajo. Data yang diperoleh dan dikumpulkan baik dalam data primer maupun data sekunder di kelolah secara kualitatif yaitu suatu cara penelitian yang dilakukan guna mencari kebenaran kualitatif. Analisa kualitatif dilakukan dengan memandang mutu peraturan perundang-undangan terhadap peristiwa hukum yang terjadi yakni pembunuhan dengan menggunakan badik. Kemudian data dipaparkan dalam uraian kata-kata secara deskriptif yaitu menjelaskan, menguraikan dan menggambarkan permasalahan serta penyelesaiannya berkaitan dengan penulisan ini.

\section{HASIL DAN PEMBAHASAN}

\section{A. Implementasi Kawasan Tanpa Rokok berdasarkan Peraturan Daerah Kabupaten Wajo}

Implementasi kebijakan merupakan cara yang dilakukan untuk mencapai sebuah tujuan pada suatu kebijakan, dalam implementasi kebijakan terdapat empat faktor atau variabel yang berpengaruh terhadap keberhasilan atau kegagalan implementasi kebijakan. ${ }^{6}$ Empat faktor tersebut adalah komunikasi, sumber daya, disposisi, dan struktur birokasi. Tujuan dari pihak rumah sakit untuk mengkomunikasikan kebijakan Kawasan Tanpa Rokok di Rumah Sakit kepada semua pihak. Komunikasi dalam implementasi kebijakan terdiri dari 3 dimensi yaitu dimensi transmisi (transmision), dimensi kejelasan (clarity), dimensi konsistensi (consistency).

Komunikasi merupakan faktor penting pertama dalam implementasi kebijakan, komunikasi bertujuan untuk memberikan informasi dari pihak yang berwenang kepada pelaksana kebijakan tentang maksud dari implementasi kebijakan. ${ }^{7}$ Pelaksana Kebijakan Kawasan Tanpa Asap Rokok di Lingkungan Rumah Sakit Umum adalah pegawai rumah sakit, masyarakat, dan pihak lain di dalam lingkungan rumah sakit.

Dimensi transmisi mengharapkan agar kebijakan disampaikan kepada sasaran kebijakan agar tujuan dari kebijakan dapat dipahami dan dilaksanakan dengan baik. Sosialisasi menjadi alat komunikasi Rumah Sakit Umum untuk menyampaikan kebijakan Kawasan Tanpa Rokok di Sekolah. Kegiatan sosialisasi pernah dilakukan pihak rumah sakit. Kegiatan sosialisasi pernah dilakukan tapi untuk yang formal itu sudah lama, data empiris hasil wawancara mengemukakan bahwa sudah 5 tahun lebih karena aturan kawasan tanpa rokok ini sudah jauh diterapkan sebelum adanya perda tentang kawasan tanpa rokok di Kabupaten Wajo.

\footnotetext{
${ }^{6}$ Sari Dewi, Dokter dan Direktur Rumah Sakit Umum Lamadukelleng (wawancara pada tanggal, 15 Agustus 2019)

${ }^{7}$ Abidin, Z., \& Hamzah, A. (2010). Pengantar dalam hukum pidana Indonesia. Yarsif Watampone. Hal, 43
} 
Pengetahuan untuk karyawan rumah sakit sudah sama dulu sosialisasinya pada waktu diterapkannya kawasan tanpa rokok ini. Kalau untuk sosialisasi yang berlanjut itu di sampaikan saja ke setiap pasien yang akan masuk melalui lembar pernyataan, dari pihak rumah sakit telah melakukan penyampaian informasi terkait kebijakan kawasan tanpa rokok. Acap kali sudah disampaikan kepada karyawan pada saat meeting, dan kalau rumah sakit ini sudah bebas rokok disertai sudah lama sudah ada juga papan-papan himbauan di sekitar area rumah sakit. Seluruh karyawan juga sampaikan dan jadi tugas mereka untuk melarang orang merokok. Pengunjung rumah sakit dapat dengan mudah membaca papan-papan larangan merokok karena sudah banyak di pasang. ${ }^{8}$ Sosialisasi sudah dilakukan secara rutin dan penuh, bahkan sudah tiga kali menyampaikan untuk tingkat Kabupaten kami memanggil semua dari tingkat desa sampai kecamatan bahkan dari pihak rumah sakit dan seluruh stakeholder terkait kawasan bebas rokok, ${ }^{9}$ dengan tujuan wajib semua sasaran kebijakan untuk menerapkan aturan tersebut tahun 2018. Untuk tahun ini 2019 kami masih memang dalam tahap sosialisai tapi untuk rumah sakit tempat kesehatan lainnya, sekolah-sekolah harus menjalankan larang merokok tersebut dan wajib dilaksanakan. ${ }^{10}$ Kabupaten Wajo masyarakatnya semua hampir mengetahui bahwa di Kabupaten Wajo sudah ada kawasan tanpa rokok, karena juga sudah sampaikan gambaran umumnya terkait kawasan tanpa rokok bersama Pemerintah Daerah, semua Camat dipanggil dari setiap Kecamatan dan diharapkan nanti dia sampaikan ke warganya, ${ }^{11}$ dalam tahapan sosialisasi tersebut disampaikan pula rencana-rencana yang sedang dilakukan termasuk penyusunan teknis penindakan pada tahun berikutnya.

Artikel ini menunjukkan bahwa Rumah Sakit Umum Daerah kabupaten Wajo sudah termasuk kawasan tanpa rokok, dan kegiatan sosialisasi kebijakan Kawasan Tanpa Rokok di Rumah Sakit Umum dilakukan sekitar kurang lebih lima tahun sampai 2019, bahkan ditingkat-tingkat yang dianggap tepat sasaran untuk dilakukan sosialisasi penerapan dari kebijakan pemerintah Daerah Kabupaten Wajo. Sosialisasi merupakan sarana komunikasi yang penting karena suatu informasi dalam kebijakan akan tersampaikan dengan baik,12 kepada sasaran dan akan mempengaruhi keberhasilan implementasi kebijakan sebagai berikut:

1) Dimensi kejelasan dalam komunikasi kebijakan menginginkan kebijakan dapat dimengerti oleh implementator dan sasaran kebijakan.

Implementator dan sasaran kebijakan sangat penting agar mengetahui tujuan dan maksud dari kebijakan tersebut. Beberapa pengunjung mengaku tidak tahu akan adanya kebijakan tersebut tetapi mereka paham bahwa sesungguhnya merokok di rumah sakit itu dilarang. “...Kalau untuk dilarang merokok di rumah sakit saya tau ji dek, tapi masih

\footnotetext{
${ }^{8}$ Wawancara Karyawan dan Sekuriti Rumah Sakit Umum Daerah Kabupaten Wajo (wawancara pada tanggal, 15 Agustus 2019)

${ }_{9}$ Pegawai Dinas Kesehatan Kabupaten Wajo (wawancara pada tanggal, 16 Agustus 2019).

10 ibid.

${ }^{11}$ Usi Tawa, Kepala Seksi Pengawasan dan Penegakan Peraturan Daerah, Satuan Polisi Pamong Praja Kabupaten Wajo (Wawancara pada tanggal, 16 Agustus 2019)

${ }_{12}$ Asmarani, A. D., \& Rahayu, D. (2019). Perlindungan Hukum Atas Keselamatan Dan Kesehatan Kerja (K3) Pekerja Rokok Di Pt Maju Melaju Lamongan. Simposium Hukum Indonesia, 1(1), 342361.
} 
banyak ji yang merokok karena kalau pegawai rumah sakit juga jarang ji menegur, sekuriti juga nda terlalu perhatikan ji kalau orang merokok, saya juga baru tau kalau ada aturannya itu kalau ada ternyata hanya tidak pernah disampaikan, jadi saya merokok saja."13 Jadi secara moralitas terdapat masyarakat memahami namun tidak melaksanakan, karena budaya hukum masyarakat Kabupaten Wajo.

“...Memang masih ada yang merokok apalagi pengunjung yang baru dan mungkin tidak paham akan adanya no smoking area, ada juga karyawan tapi merokoknya jauh-jauh jikalau mau merokok mengambil tempat didekat pos yang ada diparkiran atau dimana yang dianggap jauh dan sepi."14 Dilain sisi terdapat juga masyarakat yang memberikan tanggapan "...Saya juga tidak tau kalau ada aturannya tersendiri tentang merokok tapi susah juga kalau mau merokok harus keluar jauh-jauh."15 Jadi masyarakat memahami akan larangan merokok namun melihat adanya pihak rumah sakit yang merokok namun ditempat yang jauh dari rumah sakit ditanggapi oleh masyarakat bahwa merokok dapat dilakukan juga di sekitaran rumah sakit, jarak yang dapat dianggap mengganggu bagi masyarakat diabaikan.

Hasil observasi penulis di lapangan juga menemukan beberapa pengunjung merokok di lingkungan rumah sakit. Selain itu terdapat beberapa puntung rokok beserta bungkusnya dibuang sembarangan di lingkungan dan koridor rumah sakit. Hal tersebut menunjukan bahwa pengunjung sudah terbiasa merokok di lingkungan rumah sakit dan melanggar peraturan perundang-undangan. Beberapa data primer artikel ini yang digambarkan pada paragraf sebelumnya dapat disimpulkan bahwa penyampaian kebijakan kawasan tanpa rokok masih belum jelas seperti manfaat dari sosialisasi hukum yang dilakukan oleh pemerintah daerah. Pemahaman mengenai kebijakan tersebut khususnya pada pengunjung kemungkinan dapat terhambat apabila pihak rumah sakit tidak memperjelas kebijakan tersebut kepada pengunjung, pasien, atau pihak dari rumah sakit itu sendiri karena sosialisasi yang diadakan ditujukan hanya untuk karyawan saja yang sosialisasinya sudah di lakukan sudah beberapa tahun yang lalu, sehingga menjadi masalah yang sama seperti daerah-daerah lain di Indonesia terkait kesadaran hukum masyarakat pada kebijakan Kawasan Tanpa Rokok. ${ }^{16}$

2) Dimensi konsistensi dalam komunikasi kebijakan

Upaya menginginkan implementasi kebijakan berjalan efektif dengan perintah-perintah yang jelas dan konsisten, maka dimensi konsistensi dirumah sakit umum belum bisa dianggap sebagai sikap konsisten karena terdapat sebuah tempat di lingkungan yang digunakan khusus untuk merokok dan lingkungan tersebut masih digunakan bebas untuk merokok

\footnotetext{
13 Malla, Pengunjng Rumah Sakit Umum Daerah Kabupaten Wajo (wawancara pada tanggal, 19 Agustus 2019).

${ }^{14}$ Nasir, Sekuriti RSUD Kabupaten Wajo (wawancara pada tanggal, 20 Agustus 2019).

15 Muhammad Ilham, pengunjung RSUD Kabupaten Wajo (wawancara pada tanggal, 20 Agustus 2019)

${ }^{16}$ Hasibuan, L. R. (2019). Implementasi Peraturan Daerah Kota Medan No. 3 Tahun 2014 Tentang Kawasan Tanpa Asap Rokok Pada Kota Medan. Jurnal Hukum Responsif, 7(7), 96-101.
} 
tanpa adanya teguran dari pihak rumah sakit. Tempat yang dimaksud terletak tidak jauh dari ruangan di rumah sakit. Tempat khusus merokok tersebut merupakan tempat kebiasaan bagi para pengunjung bahkan dari sebagian karyawan rumah sakit.

Data primer artikel ini dikemukakan bahwa “...Masih banyak yang merokok didekat wc memang di situ tempat kebiasaan pengunjung keluarga pasien merokok dan bahkan saya biasa lihat karyawan juga merokok di situ memang di situ, seperti tempat untuk khusus merokok tapi karena faktor kebiasaan saja jadi di anggap di situ tempat bebas merokok untuk di rumah sakit. Di dekat wc memang jarang orang mau di tegur” . “...Memang susah karena tidak ada sanksi dan kita tidak bisa memberi sanksi dan tidak di atur kita bukan penegak hukum, jadi masih ada memang tempat pengunjung merokok agak di luar-luar, tapi kalau untuk dalam ruangan sudah tidak boleh lagi." Data primer ini menunjukkan adanya masyarakat melihat kawasan toilet merupakan kawasan yang kotor dan pantas ditempati untuk merokok, padahal sesungguhnya kawasan itu termasuk paling banyak digunakan dan dilalui oleh orang-orang di RSUD Kabupaten Wajo, definisi perokok di RSUD menunjukkan bahwa mereka menganggap udara bau toilet yang busuk sama halnya sebuah pencemaran udara yang dapat menimbulkan penyakit yang sama dapat ditimbulkan oleh rokok. Hasil wawancara di atas menunjukkan bahwa tidak adanya konsistensi antara kebijakan yang diberlakukan dengan kenyataan yang terjadi di lapangan, begitu pula mereka yang diberikan kewenangan untuk mengimplementasikan kebijakan tersebut diwilayahnya. Kebijakan Kawasan Tanpa Rokok di rumah sakit sudah jelas menegaskan bahwa lingkungan rumah sakit Umum Lamaddukelleng merupakan Kawasan Tanpa Rokok namun pimpinan RSUD Kabupaten Wajo pun belum paham cara mengefektifka Peraturan Kabupaten Wajo.

3) Dimensi Sumber Daya

Sumber daya manusia mempunyai peran yang sangat berpengaruh dalam implementasi sebuah kebijakan. Sumber daya yang tersedia diharapkan mendukung implementasi kebijakan, jika sumber daya tidak mendukung tentu saja akan menghambat pelaksanaan kebijakan. Tujuan dari sebuah kebijakan dalam sumber daya pada proses implementasi kebijakan kawasan tanpa rokok di rumah sakit berhubungan dengan kesiapan dari pihak pelaksana. Sumber daya tersebut dapat berupa sumber daya manusia, sumber daya anggaran, sumber daya peralatan, dan sumber daya kewenangan. ${ }^{17}$

Artikel ini mengungkapkan hasil penelitian mengenai sumber daya implementasi kebijakan kawasan tanpa rokok di Rumah Sakit Umum Kabupaten Wajo :

a) Sumber daya manusia dari pihak rumah sakit dapat dilihat dari jumlah pelaksana yang menangani kebijakan tersebut, keahlian yang dimiliki anggota pelaksana, informasi yang relevan tentang implementasi kebijakan dan persiapan lainnya. Sumber daya

\footnotetext{
17 Jaya, M. (2009). Pembunuh berbahaya itu bernama rokok. Yogyakarta: Riz'ma. Hal, 61
} 
manusia yang digunakan sebagai pelaksana kebijakan kawasan tanpa rokok di rumah sakit adalah pihak keamanan RSUD atau sekuriti dan seluruh karyawan, sebab jikalau mengharapkan untuk tim khusus untuk menangani masalah kebijakan tentang larangan rokok ini memang tidak ada, namun untuk pengamanan lingkungan rumah sakit kan ada sekuriti yang berperan nanti yang akan menegur atau melarang tentang masalah rokok ini, pegawai juga diminta untuk membantu menegur namun masih banyak yang acuh untuk menegur. ${ }^{18}$

Pendapat yang sama oleh pihak sekuriti: “...Jadi memang untuk disini rumah sakit saya yang patroli untuk melihat sekeliling lingkungan rumah sakit jadi saya yang di tugaskan untuk melarang orang merokok di sekitar rumah sakit sudah harus dan menjadi kewajiban untuk melarang orang yang berada di rumah sakit supaya tidak merokok." 19 Dan “...Memang agak kesulitan yah karena saya harus di pos juga harus memperhatikan kondisi orang-orang sekitar rumah sakit ini luas jadi kalau saya cuma sendiri kesulitan karena teman yang menjaga satu orang berada di dalam ruangan kalau saya patroli di area selatan rumah sakit biasanya area utara ada yang merokok jadi memang agak sulit jadi berharap juga kesadaran pengunjung dan karyawan untuk menegur ketika melihat dan melaporkan ke saya."20 Kesiapan sumber daya manusia dalam implementasi kebijakan kawasan tanpa rokok di rumah sakit Umum di tangani oleh sekuriti dan pegawai, namun dari adanya kebijakan kawasan tanpa rokok tersebut kondisi sumber daya yang ada belum dimaksimalkan. ${ }^{21}$

b) Sumber daya anggaran dalam pelaksanaan kebijakan kawasan tanpa rokok di rumah sakit Umum Lamaddukelleng sudah cukup karena program dari untuk pelaksanaan Kawasan Tanpa Rokok di rumah sakit tidak membutuhkan pendanaan yang banyak.

Pendanaan untuk kebijakan tersebut hanya terdapat pada pemasangan tanda dilarang merokok. Pemasangan tanda dilarang merokok menggunakan anggaran dari rumah sakit. "...Untuk anggaran tentang kawasn rokok ini menggunakan anggaran dari rumah sakit untuk pemasangan papan-papan dan poster terkait larangan merokok."22 Anggaran dalam pelaksanaan kebijakan kawasan tanpa rokok yang dikeluarkan hanya untuk memasang tanda larangan merokok di sekitar area rumah sakit dengan anggaran yang sudah disediakan dari rumah sakit Umum.

c) Sumber daya peralatan yang digunakan untuk melaksanakan kebijakan kawasan tanpa rokok di rumah sakit Umum hanya menggunakan tanda larangan merokok. Tidak ada peralatan khusus

\footnotetext{
18 Sari Dewi, Op.Cit.

${ }^{19}$ Ansarullah, Sekuriti RSUD Kabupaten Wajo (wawancara pada tanggal, 22 Agustus 2019)

20 ibid.

${ }^{21}$ Dussault, G., \& Dubois, C. A. (2003). Human resources for health policies: a critical component in health policies. Human resources for health, 1(1), 1.

22 Sari Dewi, Op.Cit.
} 
dari rumah sakit karena tidak ada program khusus untuk menangani kebijakan tersebut. "...Kalau untuk di rumah sakit di sini kami hanya memasang tanda larangan saja untuk tidak merokok selebihnya yang namanya perturan kan apalagi undang-undang tahu atau tidak tetap harus dilaksanakan." 23

\section{B. Faktor penghambat dari penerapan Kawasan Tanpa Rokok}

Terhadap implementasi kebijakan yang merupakan tahap penting dalam sebuah kebijakan, dimana implementasi akan mempengaruhi berhasil atau tidaknya suatu kebijakan yang telah dibuat. Kebijakan yang telah dibuat dengan baik tidak akan berjalan jika tidak diimplementasikan dan hanya akan menjadi wacana semata. ${ }^{24}$ Proses implementasi kebijakan pastinya akan dipengaruhi beberapa faktor yang menyebabkan sebuah keberhasilan maupun kegagalan. Terdapat empat faktor yang akan mempengaruhi sebuah proses implementasi kebijakan. Faktor pertama adalah bagaimana jalinan komunikasi dalam proses implementasi kebijakan. Ketersediaan sumber daya menjadi faktor berikutnya. Faktor ketiga yang mempengaruhi keberhasilan dan kegagalan dalam proses implementasi kebijakan adalah komitmen atau sikap dari pelaksana kebijakan. Faktor terkahir yaitu struktur birokrasi. ${ }^{25}$ Seluruh faktor tersebut akan menentukan pelaksanaan kebijakan sesuai dengan tujuan atau tidak.

Berdasarkan hasil wawancara, obersvasi, dan studi dokumentasi dapat dijelaskan bagaimana faktor komunikasi, ketersediaan sumberdaya, disposisi, serta struktur birokrasi akan mempengaruhi implementasi kebijakan Kawasan Tanpa Rokok di Rumah Sakit Umum Daerah Kabupaten Wajo, komunikasi kebijakan berarti merupakan proses penyampaian informasi kebijakan dari pembuat kebijakan (policy maker) kepada pelaksana kebijakan (policy implementor).

Komunikasi sangat menentukan keberhasilan pencapaian tujuan dari implementasi kebijakan publik, ${ }^{26}$ implementasi yang efektif terjadi apabila para pembuat keputusan sudah mengetahui apa yang akan mereka kerjakan. Faktor yang pertama ini mempunyai peran yang penting dalam implementasi suatu kebijakan, sebuah kebijakan harus dikomunikasikan antara pembuat kebijakan dengan pelaksana kebijakan, pelaksana kebijakan kawasan tanpa asap rokok dalam hal ini adalah pihak rumah sakit di Kabupaten Wajo. Pelaksana mempunyai tugas untuk menyampaikan infromasi mengenai kebijakan kawasan tanpa rokok kepada seluruh masyarakat selaku obyek kebijakan. ${ }^{27}$ Komunikasi harus disampaikan dengan jelas dan akurat agar mudah dimengerti dan berjalan sesuai dengan tujuan kebijakan kawasan tanpa asap rokok di rumah sakit, baik di Kabupaten Wajo maupun di daerah lainnya.

\footnotetext{
23 ibid.

24 Gedeona, H. T. (2006). Arti Penting Evaluasi Politik Formulasi Kebijakan Publik Bagi Kelangsungan Pemerintahan. Jurnal Ilmu Administrasi: Media Pengembangan Ilmu dan Praktek Administrasi, 3(2), 01.

25 Jaya, M. (2009). Op.Cit. Hal, 49

${ }^{26}$ Aswari, A. (2017). Sibernetika, Teknologi Siber dan Kebutuhan hukum.

27 Sirat, A. S. (2002). Perilaku merokok. In Laporan Akhir Surkesnas Workshop on Evidence for Decision Making (Vol. 28, pp. 291-340).
} 
Implementasi kebijakan komunikasi terdiri dari 3 dimensi yaitu dimensi transfromasi (transmission), dimensi kejelasan (clarity), dimensi konsistensi (consistency). ${ }^{28}$

a) Dimensi transformasi dalam komunikasi pelaksanaan kebijakan mengharapkan pelaksana kebijakan memberitahukan tentang kebijakan yang akan dilaksanakan. Penjelasan kebijakan mencakup tujuan yang akan dicapai dan persiapan apa saja yang dilakukan untuk mencapai tujuan kebijakan tersebut. Rumah sakit Umum Daerah melakukan komunikasi kebijakan kawasan tanpa rokok melalui cara sosialisasi. Sosialisasi dilakukan kepala rumah sakit yang lama sejak kurang lebih lima tahun yang lalu setelah terpilihnya kepala rumah sakit yang sekarang. Penyampaian informasi mengenai kebijakan kawasan tanpa rokok atau dilarang merokok juga dilakukan langsung kepada karyawan rumah sakit dan sekuriti. Komunikasi antara Kepala Rumah Sakit, Karyawan, dan security adalah menjelaskan bahwa Rumah Sakit Umum Lamaddukelleng adalah kawasan tanpa rokok. Penyampaian juga disampaikan khusus untuk seluruh pasien yang akan masuk rumah sakit melalu lembar persetujuan. Dalam lembaran tersebut salah satu poinnya yaitu rumah sakit Umum adalah kawasan tanpa rokok Kesimpulan dari penjelasan di atas adalah dimensi transisi dalam pelaksanaan kebijakan Kawasan Tanpa Rokok dilakukan dengan cara sosialisasi sejak di diberlakukannya aturan Kawasan Tanpa Rokok. Untuk penyampain lain dengan cara melalui lembar perstejuan setiap pasien yang akan masuk bahwa akan mentaati seluruh aturan yang ada di rumah sakit Umum .

b) Dimensi Kejelasan komunikasi yang dilakukan oleh pelaksana kebijakan diharapkan dapat diterima secara jelas oleh sasaran kebijakan. Kejelasan yang diterima oleh sasaran kebijakan sangat penting agar mengetahui tujuan dan maksud dari kebijakan tersebut. ${ }^{29}$ Hasil wawancara dengan pengunjung rumah sakit mengenai pelaksanaan kebijakan kawasan tanpa rokok di rumah sakit Umum menunjukkan beberapa pengunjung mengaku tidak tahu akan adanya kebijakan tersebut tetapi mereka paham bahwa merokok di rumah sakit itu tidak boleh. Hasil observasi menemukan beberapa pengunjung merokok di area larangan merokok yang ada di rumah sakit, bahkan ditemukan puntung rokok yang dibuang sembarangan di sekitar lingkungan rumah sakit. Hal tersebut mengindikasikan bahwa merokok di lingkungan rumah sakit adalah hal sudah biasa dilakukan. Hal tersebut tentu saja tidak sesuai dengan Peraturan Daerah Kabupaten Wajo No. 5 Tahun 2015 dan Peraturan Bupati nomor 8 tahun 2017 yang jelas memberikan larangan merokok di tempat kesehatan salah satuya yaitu rumah sakit. Kesimpulan

\footnotetext{
${ }^{28}$ Mu'tadin, Z. (2002). Remaja dan rokok. Jakarta: diakses dari http://www. e-psikologi. com/epsi/individual_detail. asp. (1 Desember 2019)

${ }^{29}$ Ampera, A. (2018). Tanggung jawab rumah sakit terhadap pasien dalam pelaksanaan pelayanan kesehatan. Al-Ishlah: Jurnal Ilmiah Hukum, 20(2), 59-74.
} 
dari penjelasan di atas adalah sosialisasi kebijakan kawasan tanpa rokok di rumah sakit umum masih belum jelas karena ada pengunjung yang mengaku tidak tahu mengenai kebijakan tersebut bahkan ada karyawan yang menjelaskan kalau sosialisasi itu tidak pernah dilaksanakan.

c) Dimensi konsistensi dalam implementasi kebijakan menjelaskan bahwa dimensi konsistensi menginginkan implementasi kebijakan berlangsung efektif dengan cara pemberian perintahperintah pelaksanaan harus konsisten dan jelas agar kebijakan yang diterapkan tidak membingungkan. Pelaksana kebijakan Kawasan Tanpa Rokok di rumah sakit Umum adalah Direktur Rumah Sakit, sekuriti, dan karyawan rumah sakit. Pihak rumah sakit sudah memasukan aturan larangan merokok dalam tata tertib rumah sakit Umum. Namun, konsistensi dalam pelaksanaan kebijakan di rumah sakit Umum belum terlihat karena belum terdapat tempat khusus untuk merokok. Sedangkan dalam Peraturan Daerah Kabupaten Wajo Nomor 5 Tahun 2015 tentang Kawasan Tanpa Rokok menjelaskan bahwa pimpinan atau penanggung jawab Kawasan Tanpa Rokok wajib menyiapkan tempat khusus untuk merokok.

1) Sumber Daya

Sumber daya menjadi faktor pendukung keberhasilan komunikasi yang dilakukan oleh pelaksana kebijakan kepada objek kebijakan. ${ }^{30}$ Sumber daya pada proses implementasi kebijakan kawasan tanpa rokok di Rumah Sakit berhubungan dengan kesiapan dari pihak pelaksana. Sumber daya tersebut dapat berupa sumber daya manusia, sumber daya anggaran, sumber daya peralatan, dan sumber daya kewenangan.

(a.) Sumber daya manusia merupakan salah satu variabel yang mempengaruhi keberhasilan dan kegagalan pelaksana kebijakan. Sumber daya manusia (staff), harus cukup (jumlah) dan cakap (keahlian), oleh karena itu, sumberdaya manusia harus ada kegiatan dan kelayakan antara jumlah staf yang dibutuhkan dan keahlian yang dimiliki sesuai dengan tugas pekerjaan yang ditanganinya, manusia dalam implementasi kebijakan kawasan tanpa rokok di rumah sakit Umum menggunakan pihak keamanan atau sekuriti dan dibantu oleh karyawan. Namun sekuriti tidak bisa sepenuhnya menghindari aktivitas merokok oleh pengunjung rumah sakit karena kekurangan pelaksana di lingkungan rumah sakit yang bisa mengamati dan menegur orang yang merokok.

(b.) Sumber daya anggaran yang digunakan untuk pelaksanaan kebijakan kawasan tanpa rokok Saat ini jumlah pelaksana kebijakan di rumah sakit Umum masih kurang dan terkendala antar pelaksana tidak adanya tim khusus untuk melaksanakan

${ }^{30}$ Edward (2000), Probably the most essential recourses in implementing policy is staff. Gramedia Jakarta. Hal, 71 
kawasan tanpa rokok. Sumber anggarkan secara khusus oleh pihak rumah sakit. Pihak rumah sakit Umum tidak menganggarkan khusus karena tidak ada program khusus untuk menanggapi kebijakan tersebut. Sosialisasi menjadi langkah awal pihak rumah sakit menanggapi kebijakan tersebut namun sosialisasi yang dilakukan tidak membutuhkan anggaran karena sosialisasi yang dilakukan hanya bentuk penyampaian ke sekuriti dan Pengawai.

(c.) Sarana yang digunakan untuk operasionalisasi implementasi suatu kebijakan yang meliputi gedung, tanah, dan sarana yang semuanya akan memudahkan dalam memberikan pelayanan dalam implementasi kebijakan. Artikel ini memandang bahwa sumber daya peralatan menjadi hal yang penting dalam implementasi kebijakan. Sarana dan prasarana digunakan untuk menunjang pelaksanaan kebijakan, dan implementasi kebijakan kawasan tanpa rokok juga membutuhkan peralatan untuk menunjang keberhasilan tujuan kebijakan. Peraturan Daerah Kabupaten Wajo No. 5 Tahun 2015 tentang Kawasan Tanpa Rokok memberikan perintah kepada pimpinan atau penanggung jawab kawasan tanpa rokok untuk memasang tanda kawasan tanpa rokok dan tempat khusus untuk merokok di tempat Kawasan Tanpa Rokok. Tujuan pelaksanaan kebijakan kawasan tanpa rokok di RSUD kabupaten Wajo sudah memasang tanda Kawasan Tanpa Rokok di lingkungan rumah sakit namun untuk khusus tempat merokok belum ada. Untuk sumber peralatan yang lain tidak atur khusus untuk mendukung kebijakan kawasan tanpa rokok di rumah sakit Umum.

(d.) Sumber daya informasi dan kewenangan yang relevan dan cukup tentang berkaitan dengan bagaimana cara mengimplementasikan suatu kebijakan, dimana bertujuan untuk digunakan untuk membuat keputusan sendiri dalam bingkai melaksanakan kebijakan yang menjadi kewenangannya. sumber daya kewenangan menjadi kekuatan oleh suatu lembaga untuk mempengaruhi lembaga tersebut dalam melaksanakan suatu kebijakan, dan kewenangan tersebut sangat penting ketika suatu lembaga dihadapkan suatu masalah dan harus segera diselesaikan dengan suatu keputusan. ${ }^{31}$ Namun kewenangan yang dimiliki oleh kepala rumah sakit belum bisa memaksimalkan pelaksanaan kebijakan kawasan tanpa rokok di rumah sakit umum.

Belum adanya keputusan dari kepala rumah sakit yang dapat mengkontrol para perokok yang berada di lingkungan rumah sakit membuat kesiapan dari pihak rumah sakit menjadi masih kurang. Belum ada program khusus dari rumah sakit yang mendukung implementasi kebijakan kawasan tanpa rokok selain sosialisasi yang dilakukan juga sejak kurang lebih lima tahun yang lalu yang dilakukan. Belum adanya program lanjutan yang mendukung kebijakan tersebut secara tidak langsung Kepala Rumah sakit belum memaksimalkan. Hasil observasi juga menemukan sarana

31 Edward 92000). ibid. hal, 29 
pendukung yang dibuat pihak rumah sakit berupa tanda tulisan dilarang merokok diacuhkan oleh beberapa perokok yang berkunjung di rumah sakit.

\section{2) Disposisi}

Artikel ini menganalisi bahwa sikap atau komitmen dari pelaksana kebijakan dibutuhkan dalam implementasi kebijakan. Komitmen yang kuat dari pelaksana kebijakan dapat mensukseskan implementasi kebijakan, untuk itu tuntutan komitmen pada pelaksana kebijakan harus kuat dan penuh dedikasi terhadap pelaksanaan sebuah kebijakan. ${ }^{32}$ Olehnya penulis menyatakan bahwa implementasi kebijakan kawasan tanpa rokok di Rumah Sakit Umum Lamaddukelleng yang dapat dilihat pada saat wawancara dan observasi menunjukan bahwa sikap pelaksana kebijakan masih belum bisa mendukung sepenuhnya terhadap pelaksanaan kebijakan kawasan tanpa rokok di rumah sakit, dengan belum adanya tempat khusus untuk merokok sebagai solusi klasik. Beberapa pelaksana menunjukan sikap yang tidak mendukung kebijakan kawasan tanpa rokok, diantaranya karyawan yang acuh terhadap orang yang merokok di rumah sakit dan kesiapan pelaksana seperti sekuriti yang masih kesulitan dalam menangani perokok yang berada di lingkungan rumah sakit Umum Lamaddukelleng.

3) Struktur Birokrasi

birokrasi merupakan faktor yang perlu diperhatikan selain komunikasi, sumber daya, dan disposisi. Struktur birokrasi mempunyai pengaruh dalam implementasi kebijakan, saat implementasi kebijakan akan melibatkan banyak orang di dalamnya, maka Standar Operasional Prosedur (SOP) dibuat untuk mempermudah impelementasi kebijakan dan memberi pedoman kepada pelaksana kebijakan. ${ }^{33}$ Struktur birokrasi diperlukannya pembagian tugas tanggung jawab, kegiatan atau program pada beberapa unit kerja yang sesuai dengan bidangnya masing-masing. Adanya hal tersebut maka implementasi akan lebih efektif karena dilaksankan oleh organisasi yang berkompeten dan kapabel. ${ }^{34}$

Artikel ini mengemukakan dari hasil observasi melihat bahwa struktur birokrasi dalam implementasi kebijakan kawasan tanpa rokok di rumah sakit Umum belum dibuat pedoman berupa SOP secara jelas, yang bertujuan untuk mengatur pembagian tugas pelaksana kebijakan sehingga implementasi kebijakan kawasan tanpa rokok kurang berjalan efektif. Pihak rumah sakit juga tidak memiliki struktur dan tidak memiliki tim khusus untuk kawasan tanpa rokok sehingga pelaksana

\footnotetext{
32 Purwanto, E. A. (2012). Implementasi Kebijakan Publik Konsep dan Aplikasinya di Indonesia (No. 1). 2012.

${ }^{33}$ Komasari, D., \& Helmi, A. F. (2000). Faktor-faktor penyebab perilaku merokok pada remaja. Jurnal Psikologi, 27(1), 37-47.

${ }^{34}$ Komasari, D., \& Helmi, A. F. (2000). ibid.
} 
kesulitan dalam mensukseskan kebijakan tersebut. Pembagian tugas yang tidak terlalu rumit dalam pelaksanaan kebijakan kawasan tanpa rokok di rumah sakit Umum ternyata masih belum bisa dimaksimalkan, terdapat banyaknya pelanggaran yang terjadi di rumah sakit tersebut.

\section{SIMPULAN DAN SARAN}

Komunikasi proses penyampain tentang kebijakan Kawasan Tanpa Rokok di rumah Sakit Umum Lamaddukelleng belum maksimal karena masih banyak masyarakat yang hanya sekedar mengetahui larangan merokok di rumah sakit tapi tidak mengetahui isi dari kebijakan atau batasan-batasan untuk tidak merokok di Kawasan Tanpa Rokok. Hal tersebut di sebabkan oleh proses penyampaian yang tidak melibatkan sasaran kebijakan. Masih banyak juga dari pihak rumah sakit tidak dapat menegur atau melarang pelanggar secara terus menerus diakibatkan karena tidak mengetahui kebijakan terseut dan tidak bisa meninggalkan kewajiban pokoknya sebagai karyawan rumah sakit.

Sumber daya pelaksanaan Kawasan Tanpa Rokok di rumah sakit Umum mengeluarkan angagaran untuk pemasangan tanda-tanda larangan merokok. Namun anggaran yang mesti di keluarkan untuk membuat tempat khusus untuk merokok itu tidak laksanakan karena pihak rumah sakit tidak peduli untuk orang yang merokok melainkan mengharap kesadaran para pengunjung yang merokok. Terkait sumber daya manusia pihak rumah sakit masih kekurangan untuk mendukung kebijakan Kawasan Tanpa Rokok, karena beberapa pelaksana KTR di rumah sakit Umum harus melakukan tugas yang multifungsi sehingga kesulitan dalam menjalankan tugasnya. Hal ini berdamkan penyelenggaraan kawasan tanpa rokok tidak dapat terlaksana dengan baik. Begitupun dengan struktur birokrasi dalam pelaksanaan kawasan tanpa rokok di rumah sakit Umum tidak memiliki pedoman atau SOP yang jelas terkait larangan merokok di lingkungan rumah sakit. Hal tersebut terlihat pihak rumah sakit memang kurang serius dalam menerapkan kebijakan kawasan tanpa rokok. Tidak adanya tim khusus untuk menangani hal tersebut. Pembagian tugas atau unit terkait kebijakan kawasan tanpa rokok di rumah itu tidak di indahkan.

Artikel ini merekomendasikan agar di bentuk tim khusus untuk dapat mengontrol dan menghentikan aktivitas merokok di lingkungan rumah sakit. Pembuatan tempat khusus untuk merokok di area rumah sakit yang tidak mengganggu kondisi lingkungan rumah sakit. Harusnya terdapat pihak yang bertanggung jawab dalam penegakan aturan kawasan tanpa rokok seperti satpol PP dapat menegakkan Perda KTR yang telah di tetapkan. Selain itu perlu peran teknologi dengan meyediakan media sosialisasi dalam bentuk video atau pengeras suara terkait adanya aturan Kawasan Tanpa Rokok di rumah sakit Umum. Agar pengunjung dapat memahami dengan jelas dan selalu mengingat bahwa rumah sakit Umum Lamaddukelleng harus bebas dari asap rokok.

\section{DAFTAR RUJUKAN}

Abidin, Z., \& Hamzah, A. (2010). Pengantar dalam Hukum Pidana Indonesia. Yarsif Watampone. 
Akib, M. (2015). Penegakan Hukum Lingkungan Dalam Perspektif HolistikEkologis. Graha Ilmu.

Ampera, A. (2018). Tanggung jawab rumah sakit terhadap pasien dalam pelaksanaan pelayanan kesehatan. Al-Ishlah: Jurnal Ilmiah Hukum, 20(2), 59-74.

Asmarani, A. D., \& Rahayu, D. (2019). Perlindungan Hukum Atas Keselamatan Dan Kesehatan Kerja (K3) Pekerja Rokok Di Pt Maju Melaju Lamongan. Simposium Hukum Indonesia, 1(1), 342-361.

Aswari, A. (2017). Sibernetika, Teknologi Siber dan Kebutuhan hukum.

Chazawi, A. (2001). Kejahatan Terhadap Tubuh Dan Nyawa. Jakarta: Raja Grafindo Persada.

Dussault, G., \& Dubois, C. A. (2003). Human resources for health policies: a critical component in health policies. Human resources for health, 1(1), 1.

Edward (2000). Probably the most essential recourses in implementing policy is staff. Gramedia Jakarta.

Ellizabet, A. L. (2010). Stop Merokok; Sekarang atau Tidak Sama sekali. Bangun Tapan. Yogyakarta: Garai Ilmu.

Gedeona, H. T. (2006). Arti Penting Evaluasi Politik Formulasi Kebijakan Publik Bagi Kelangsungan Pemerintahan. Jurnal Ilmu Administrasi: Media Pengembangan Ilmu dan Praktek Administrasi, 3(2), 01.

Hasibuan, L. R. (2019). Implementasi Peraturan Daerah Kota Medan No. 3 Tahun 2014 Tentang Kawasan Tanpa Asap Rokok Pada Kota Medan. Jurnal Hukum Responsif, 7(7), 96-101.

Jaya, M. (2009). Pembunuh berbahaya itu bernama rokok. Yogyakarta: Riz'ma.

Komasari, D., \& Helmi, A. F. (2000). Faktor-faktor Penyebab Perilaku Merokok Pada Remaja. Jurnal Psikologi, 27(1), 37-47

Mu'tadin, Z. (2002). Remaja dan rokok. Jakarta: diakses dari http://www. epsikologi. com/epsi/individual_detail.asp.

Sirat, A. S. (2002). Perilaku merokok. In Laporan Akhir Surkesnas Workshop on Evidence for Decision Making (Vol. 28, pp. 291-340).

Purwanto, E. A. (2012). Implementasi Kebijakan Publik Konsep dan Aplikasinya di Indonesia (No. 1). 2012.

Wati, A. R. A. (2017). Penerapan Kawasan Tanpa Rokok Berdasarkan Peraturan Daerah Kota Metro Nomor 4 Tahun 2014. Jurnal Hima Han, 4(2). 